Jurnal IImu Keperawatan Medial Bedah 2 (1), Mei 2019, 1-54

ISSN 2338-2058 (print), ISSN 2621-2986 (online)

\title{
PIJAT KAKI EFEKTIF MENURUNKAN FOOT OEDEMA PADA PENDERITA CONGESTIVE HEART FAILURE (CHF)
}

\author{
Kasron* \\ Engkartini** \\ *Program Studi S1 Keperawatan STIKES Al-Irsyad Al-Islamiyyah Jln. Cerme No 24 Sidanegara \\ Cilacap 53222 \\ **Program Studi S1 Keperawatan STIKES Al-Irsyad Al-Islamiyyah Jln. Cerme No 24 \\ Sidanegara Cilacap 53222
}

Corresponding Author: kasron@stikesalirsyadclp.ac.id

\begin{abstract}
Abstrak
Oedema kaki merupakan salah satu gejala pada pasien CHF. Oedema kaki dapat menyebabkan penurunan kualitas hidup, ketidaknyamanan, perubahan postur tubuh, menurunkan mobilitas dan meningkatkan resiko jatuh, gangguan sensasi di kaki dan menyebabkan perlukaan di kulit. Tujuan penelitian untuk mengetahui pengaruh pijat kaki terhadap penurunan oedema kaki pada pasien CHF. Metode penelitian menggunakan quasi-experiment dengan pendekatan pre-post test without control group. Responden penelitian adalah pasien CHF yang mengalami oedema kaki, pemilihan responden menggunakan non-probability sampling dengan metode accidental sampling. Responden diukur lingkar oedema pada lingkar angkle, instep dan MP-Joint menggunakan metline pada sebelum intervensi, hari pertama, kedua dan ketiga. Analisis statistik menggunakan wilcoxon test. Sejumlah 13 responden memenuhi kriteria penelitian. Pada kaki kanan lingkar angkle pre: $27,7 \pm 1,8$, post $1: 27,6 \pm 1,8$, post $227,5 \pm 1,7$, post $3: 27,2 \pm 1,7$, lingkar instep pre: $27,6 \pm 1,7$, post 1 : $27,6 \pm 1,8$, post 2: 27,2 $\pm 1,7$, post 3: 26,9 $\pm 1,7$, lingkar MP-joint pre: $27,0 \pm 1,6$, post 1:27,0 11,6 , post 1: $27,0 \pm 1,6$, post $2: 26,7 \pm 1,7$, post 3: $26,3 \pm 1,7$. Kaki kiri lingkar angkle pre: $27,6 \pm 1,8$, post 1 : $27,6 \pm 1,8$, post $2: 27,3 \pm 1,8$, post $3: 27,0 \pm 1,8$, lingkar instep pre: $27,6 \pm 1,7$, post $1: 27,5 \pm 1,7$, post 2 : $27,2 \pm 1,7$, post $3: 26,8 \pm 1,7$, lingkar MP-joint pre: $27,0 \pm 1,6$, post $1: 26,9 \pm 1,8$, post $2: 26,5 \pm 1,8$, post 3: $26,2 \pm 1,8$. Hasil analisis menunjukan bahwa terdapat perbedaan yang bermakna lingkar oedema pada kaki kanan setelah hari kedua dan ketiga dengan $p$-value $<0,001$. Kesimpulan penelitian adalah terdapat perbedaan lingkar oedema angkle, instep, dan MP-joint pada hari kedua dan ketiga setelah pemijatan kaki pada pasien CHF yang mengalami oedema kaki. Perlu penelitian lanjutan untuk penatalaksanaan oedema kaki pada pasien CHF yang mengalami oedema kaki.
\end{abstract}

Kata kunci: CHF, Foot Oedema, Pijat Kaki 
Jurnal IImu Keperawatan Medial Bedah 2 (1), Mei 2019, 1-54

ISSN 2338-2058 (print), ISSN 2621-2986 (online)

\section{PENDAHULUAN}

Congestive Heart Failure (CHF) adalah ketidakmampuan otot jantung memompakan sejumlah darah untuk memenuhi kebutuhan metabolik tubuh. CHF adalah sebuah kondisi dari kardiovaskuler dimana jantung tidak bisa memompa darah secara adekuat untuk memenuhi kebutuhan metabolisme dari jaringan tubuh (Desai, Lewis, Li, \& Solomon, 2012). Beberapa faktor resiko gagal jantung adalah kebiasaan merokok, kurang aktivitas fisik, perubahan pola diet, kelebihan berat badan, hiperlipidemia, diabetes, hipertensi, usia, jenis kelamin dan keturunan. Berdasarkan penelitian diketahui penyebab utama CHF adalah hipertensi dan penyakit arteri koronaria (Savage et al., 1998). CHF merupakan tahap akhir dari seluruh penyakit jantung dan merupakan penyebab peningkatan morbiditas dan mortalitas pasien jantung. Berdasarkan data World Health Organisations (WHO) risiko kematian akibat gagal jantung berkisar antara 5-10\% pertahun pada gagal jantung ringan yang akan meningkat menjadi 30-40\% pada gagal jantung berat (World Health Organization (WHO), 2015).

Penyakit CHF meningkat sesuai dengan perkembangan usia, prevalensi CHF di dunia sekitar 1\% pada orang yang berusia 50-59 tahun, 10\% pada usia lebih dari 65 tahun, dan 50\% pada usia lebih dari 85 tahun. (Collier et al., 2011). Pada negara berkembang prevalensi CHF sekitar 1$2 \%$ dari populasi dewasa. Prevalensi meningkat lebih dari 10\% pada usia lebih dari 70 tahun (Murberg \& Bru, 2001).

Prevalensi CHF di Indonesia adalah 0,13\%, tertinggi di Yogyakarta 0,25\%, disusul Jawa Timur 0,19\%, dan ketiga di Jawa Tengah 0,18\%. Berdasarkan jenis kelamin kejadian CHF pada laki-laki adalah $0,1 \%$ dan perempuan $0,2 \%$. Berdasarkan usia pasien kejadian CHF pada usia 1534 tahun adalah 0,07\%, usia 35-54 tahun 0,28\%, 55-74 tahun 0,87\%, lebih dari 75 tahun 0,41\%. (Dinas Kesehatan Republik Indonesia, 2013).

Gejala penyakit CHF yang biasa muncul adalah extertional dyspnoea, orthopnoea, paroxysmal nocturnal dyspnoea, batuk kering, kelelahan dan kelemahan, pusing atau palpitasi. Gejala penyakit CHF yang berkaitan dengan retensi cairan adalah nyeri epigastrik, distensi abdomen, ascites, oedema sakral dan oedema peripheral (Panel et al., 2011). Persentase gejala pada CHF adalah dispnoea (52\%), orthopnoea (81\%), paroxysmal nocturnal dyspnoea (76\%), oedema (80\%) (Remme \& Swedberg, 2001). 
Jurnal IImu Keperawatan Medial Bedah 2 (1), Mei 2019, 1-54

ISSN 2338-2058 (print), ISSN 2621-2986 (online)

Oedema kaki didefinisikan sebagai akumulasi cairan di kaki dan tungkai yang di akibatkan oleh ekspansi volume interstisial atau peningkatan volume ekstraseluler (Cho \& Atwood, 2002). Oedema kaki akan menyebabkan penurunan fungsi kesehatan dan kualitas hidup (HR-QOL), ketidaknyamanan, perubahan postur tubuh, menurunkan mobilitas dan meningkatkan resiko jatuh, gangguan sensasi di kaki dan menyebabkan perlukaan di kulit (Rahnavard, Nodeh, \& Hatamipour, 2014).

Oedema kaki dapat dikurangi dengan melakukan penatalaksanaan pemijatan pada kaki, dimana dengan pijat kaki akan menstimulasi pengeluaran cairan melalui saluran limfe ke bagian yang lebih proksimal, sehingga menurunkan kejadian oedema kaki (Ciocon, Galindo-Ciocon, \& Galindo, 1995; Ely, Osheroff, Chambliss, \& Ebell, 2006). Beberapa penelitian menjelaskan bahwa pijat kaki dapat menurunkan oedema pada kaki, hasil penelitian pada perawat setelah bekerja shift menunjukan pijat kaki mandiri dapat menurunkan tingkat nyeri dan oedema kaki perawat yang bekerja setelah shift dinas (Soran et al., 2008). Hasil penelitian pada wanita hamil yang mengalami oedema kaki dengan dilakukan pijat kaki dapat menurunkan oedema kaki (Çoban \& Şirin, 2010). Berdasarkan penelitian Wei-Ling Chen dkk (2013) dengan efek pijat punggung pada pasien CHF dapat diperoleh hasil bahwa efek pijat punggung dapat menurunkan kecemasan, meningkatkan kenyamanan dan meningkatkan respon fisiologis tubuh (menurunkan tekanan darah sistolik dan diastolik, menurunkan denyut jantung, menurunkan respiratory rate, meningkatkan saturasi oksigen) (Chen et al., 2013).

Pijat adalah sentuhan secara sistematis yang memanipulasi jaringan lunak dari tubuh untuk meningkatkan kenyamanan dan penyembuhan (Patient, 2010). Berdasarkan penelitian bahwa keuntungan utama pemijatan adalah meningkatkan relaksasi, meningkatkan aliran darah, meningkatkan penyembuhan otot, mengurangi spasme otot, dan menurunkan kecemasan (Bayrakci Tunay, Akbayrak, Bakar, Kayihan, \& Ergun, 2010; Be, Into, \& Hospitals, 2013; Gazillo \& Middlemas, 2001; Ragsdale, n.d.). Pijat kaki adalah gerakan sederhana yang berirama memijat kulit bagian telapak kaki untuk menstimulasi aliran getah bening ke sistem sirkulasi darah, dengan serangkain tekhnik, metode dan alat pijat tertentu (Çoban \& Şirin, 2010; Hulme, Waterman, \& Hillier, 1999; Shimizu, 2009).

Hasil Survei awal yang dilakukan di RSUD Cilacap pada tahun 2013 (Januari-Nopember) diketahui jumlah kasus CHF yaitu pada pasien usia 30-60 tahun sebanyak 62 pasien $(29,41 \%)$ dan usia lebih dari 60 tahun sebanyak 125 (70,59\%) (Rekam Medis RSUDC, 2013). Penyebab CHF 
Jurnal IImu Keperawatan Medial Bedah 2 (1), Mei 2019, 1-54

ISSN 2338-2058 (print), ISSN 2621-2986 (online)

sebagian besar adalah diabetes, hipertensi dan penyakit arteri koronaria. Gejala yang muncul pada pasien CHF adalah sesak nafas, kelelahan, kelemahan, pusing dan oedema kaki. Pada pasien CHF yang mengalami oedema kaki di RSUD Cilacap belum dilakukan penatalaksanaan untuk mengurangi gejala oedema kaki tersebut. Tujuan penelitian ini adalah mengetahui pengaruh pijat kaki terhadap penurunan oedema kaki pada pasien CHF.

\section{METODE PENELITIAN}

Penelitian dilakukan di RSUD Cilacap, ruang penyakit dalam. Jenis penelitian quasi experimental, dengan pendekatan pre-posttest without control group design. Metline digunakan untuk mengukur lingkar FO yaitu pada lingkar Ankle, lingkar Instep, lingkar sendi MP (metatarsalphalangs-joint). Pengambilan data dengan mengukur lingkar FO setelah tindakan pada hari ke-1,2 dan 3. Intervensi pemijatan selama 3 hari dengan durasi \pm 20 menit. Pengambilan sample dengan metode accidental sampling dengan cara memilih semua individu yang ditemui selama 1 bulan berjalan dan sesuai dengan kriteria yang sudah ditetapkan yaitu: 1). Pasien gagal jantung stabil yang ditandai dengan: tidak ada nyeri dada, tidak sesak nafas saat istirahat, denyut nadi istirahat 50-90x/menit dan reguler, tekanan darah sistolik 100-150 mmHg, dan tekanan darah diastolik 60$90 \mathrm{mmHg}$, 2). Tidak ada kontraindikasi pemijatan, memar, radang, luka, demam, infeksi kulit, 3). Bersedia menjadi responden. Sedangkan kriteria eksklusi sampel dalam penelitian ini adalah: 1). NYHA fungsional kelas IV, 2). Aritmia pada saat istirahat, 3). Denyut jantung saat istirahat lebih dari 100x/menit. Analisis menggunakan Wilcoxon test pada setiap pengukuran. 


\section{HASIL DAN PEMBAHASAN}

Penelitian dilakukan pada sejumlah 13 pasien CHF yang mengalami oedema kaki dan sesuai dengan kriteria inklusi.

Berikut deskripsi karakteristik responden penelitian.

Tabel 1

Deskripsi Karakteristik Pasien CHF Yang Mengalami Oedema Kaki (n=13)

\begin{tabular}{llc}
\hline No & Variabel & Deskripsi \\
\hline 1 & Umur (tahun) & $54,23 \pm 5,8$ \\
2 & Jenis kelamin & \\
& Laki-laki & $8(61,5 \%)$ \\
& Perempuan & $5(38,5 \%)$ \\
3 & Pendidikan & \\
& Tidak lulus SD & $1(7,7 \%)$ \\
& SD & $1(7,7 \%)$ \\
& SMP & $6(46,2 \%)$ \\
& SMA & $5(38,5 \%)$ \\
& Grade CHF & \\
& II & $4(30,8 \%)$ \\
& III & $9(69,2 \%)$ \\
\hline
\end{tabular}

Dari tabel 1 diketahui umur responden rata-rata 54,23 tahun jenis kelamin sebagian besar laki-laki pendidikan sebagian besar, dan sebagian besar pada grade NYHA III.

Data lingkar oedemaa dilakukan uji normalitas menggunakan Uji Shapiro Wilk menunjukan semua data tidak berdistribusi normal. Sehingga analisis bivariat antar pengukuran dapat menggunakan uji Wilcoxon. 
Tabel 2

Analisis Bivariat Antar Pengukuran Lingkar Oedema Kaki

Pasien CHF Yang Mengalami Oedema Kaki

\begin{tabular}{|c|c|c|c|c|c|}
\hline No & Kaki & Lingkar & Pengukuran & Nilai & p-value \\
\hline \multirow[t]{15}{*}{1} & \multirow[t]{15}{*}{ Kanan } & \multirow[t]{5}{*}{ Angkle } & Pre 0 & $27,7 \pm 1,8$ & \multirow[b]{2}{*}{0,790} \\
\hline & & & \multirow{2}{*}{ Post 1} & $276+18$ & \\
\hline & & & & $2,0=1,0$ & \multirow[t]{2}{*}{$<0,001$} \\
\hline & & & Post 2 & $27,5 \pm 1,7$ & \\
\hline & & & Post 3 & $27,2 \pm 1,7$ & $<0,001$ \\
\hline & & \multirow[t]{5}{*}{ Instep } & Pre 0 & $27,6 \pm 1,7$ & \multirow[b]{2}{*}{0,082} \\
\hline & & & \multirow{2}{*}{ Post 1} & $276+18$ & \\
\hline & & & & $21,0+1,0$ & \multirow{2}{*}{$<0,001$} \\
\hline & & & Post 2 & $27,2 \pm 1,7$ & \\
\hline & & & Post 3 & $26,9 \pm 1,7$ & $<0,001$ \\
\hline & & \multirow[t]{5}{*}{ MP-Joint } & Pre 0 & $27,0 \pm 1,6$ & \multirow[b]{2}{*}{0,165} \\
\hline & & & Poct 1 & $270+16$ & \\
\hline & & & & & $<0,001$ \\
\hline & & & Post 2 & $26,7 \pm 1,7$ & \multirow{2}{*}{$<0,001$} \\
\hline & & & Post 3 & $26,3 \pm 1,7$ & \\
\hline \multirow[t]{15}{*}{2} & \multirow[t]{15}{*}{ Kiri } & \multirow[t]{5}{*}{ Angkle } & Pre 0 & $27,6 \pm 1,8$ & \multirow[b]{2}{*}{0,018} \\
\hline & & & & & \\
\hline & & & Post 1 & $2 /, 6 \pm 1,8$ & $<0,001$ \\
\hline & & & Post 2 & $27,3 \pm 1,8$ & \\
\hline & & & Post 3 & $27,0 \pm 1,8$ & $<0,001$ \\
\hline & & Instep & Pre 0 & $27,6 \pm 1,7$ & \\
\hline & & & Post 1 & $27,5 \pm 1,7$ & 0,082 \\
\hline & & & & & $<0,001$ \\
\hline & & & Post 2 & $27,2 \pm 1,7$ & $\angle 0001$ \\
\hline & & & Post 3 & $26,8 \pm 1,7$ & $<0,001$ \\
\hline & & MP-Joint & Pre 0 & $27,0 \pm 1,6$ & \\
\hline & & & Post 1 & $26.9 \pm 18$ & 0,249 \\
\hline & & & & & $<0,001$ \\
\hline & & & Post 2 & $26,5 \pm 1,8$ & \\
\hline & & & Post 3 & $26,2 \pm 1,8$ & 0,001 \\
\hline
\end{tabular}

Ket:Pre 0: pengukuran sebelum perlakuan, Post 1: pengukuran setelah perlakuan hari pertama, Post 2: pengukuran setelah perlakuan hari kedua, Post 3: pengukuran setelah perlakuan hari ketiga, *: Uji wilcoxon test, bermakna pada p-value $<0,05$. 
Jurnal IImu Keperawatan Medial Bedah 2 (1), Mei 2019, 1-54

ISSN 2338-2058 (print), ISSN 2621-2986 (online)

Penatalaksanaan pada pasien CHF sangat kompleks, semakin banyak komplikasi yang muncul pada pasien maka akan semakin banyak intervensi yang perlu diberikan (Chatterjee, 2002). Oedema kaki merupakan komplikasi yang sering terjadi pada pasien CHF. (AuCoin, 2011) Oedema kaki sendiri merupakan salah satu tanda bahwa penyakit CHF yang diderita oleh pasien sudah dalam kondisi komplikasi lanjut dan berlangsung lebih lama sehingga sistem pompa jantung mengalami penurunan (Rahnavard et al., 2014; Trayes, Studdiford, Jefferson, Tully, \& Clinic, 2013).

Oedema kaki pada pasien CHF lebih sering terjadi pada pasien dengan kelemahan jantung akibat adanya akumulasi cairan di kaki dan tungkai yang di akibatkan oleh ekspansi volume interstisial atau peningkatan volume ekstraseluler (Cho \& Atwood, 2002). Cairan tubuh yang berada di ekstraseluler mengalami peningkatan jumlahnya, yang diakibatkan oleh perubahan dalam keseimbangan tekanan hidrostatik dan tekanan onkotik. Akibat ketidakseimbangan tersebut menyebabkan kedua kompartemen cairan tubuh terganggu dalam lintasan cairan antar kompartemen tersebut. Untuk mengatasi gangguan pintasan cairan dalam kedua kompartemen tersebut perlu perbaikan keseimbangan yang melibatkan tekanan hidrostatik, onkotik, plasma, permeabilitas dan dinding pembuluh (Cho \& Atwood, 2002).

Oedema kaki secara umum dapat dikurangi dengan melakukan penatalaksanaan pemijatan pada kaki, dimana dengan pijat kaki akan menstimulasi pengeluaran cairan melalui saluran limfe ke bagian yang lebih proksimal, sehingga menurunkan kejadian oedema kaki (Ciocon et al., 1995; Ely et al., 2006). Teknik pijat yang dilakukan dalam penelitian ini sesuai prosedur yang dilakukan oleh Shimizu (2009), dimana Shimizu melakukan teknik pijat tersebut dalam penelitian yang digunakan pada wanita hamil yang mengalami oedema kaki fisiologis. Hasil penelitian tersebut menunjukan terdapat pengaruh pijat kaki dengan penurunan oedema kaki pada wanita hamil (Shimizu, 2009).

Hasil penelitian ini menunjukan bahwa saat hari pertama tidak terdapat perbedaan lingkar oedema pada kaki kanan dan kiri untuk lingkar instep (kanan: p-value: 0,082; kiri: p-value: 0,082 ) dan MP joint (kanan: p-value :0,165; kiri: p-value: 0,249) saat hari pertama proses pemijatan. Namun hasil berbeda pada lingkar ankle hari pertama yaitu untuk kaki kanan menunjukan tidak ada perbedaan yang bermakna dengan p-value 0,790, sedangkan pada kaki kiri menunjukan perbedaan yang bermakna dengan $p$-value 0,018 . 
Jurnal IImu Keperawatan Medial Bedah 2 (1), Mei 2019, 1-54

ISSN 2338-2058 (print), ISSN 2621-2986 (online)

Pada kaki kiri pada area lingkar ankle lebih cepat mengalami penurunan oedema kaki dimungkinkan terjadi karena pada saluran pembuluh limfe pada area distal lebih mudah untuk mengembang atau dilatasi karena proses pemijatan. Serta disebabkan secara umum pada responden ekstremitas bawah kiri kurang dominan dalam melakukan aktivitas keseharian, sehingga ektremitas bawah kiri secara anatomi lebih kecil dibandingakan ekstremitas bawah kanan.

Hasil penelitian saat hari kedua menunjukan bahwa semua lingkar oedema dibandingkan pada hari pertama menunjukan terdapat perbedaan lingkar oedema baik pada lingkar ankle, instep maupun MP joint, baik pada kaki kanan maupun pada kaki kiri dengan $p$-value $<0,001$. Demikian juga pada hari ketiga, hasil penelitian menunjukan bahwa semua lingkar oedema dibandingkan pada hari pertama menunjukan terdapat perbedaan lingkar oedema baik pada lingkar ankle, instep maupun MP joint, baik pada kaki kanan maupun pada kaki kiri dengan $p$-value $<0,001$.

Hasil penelitian menunjukan persamaan dengan beberapa penelitian sejenis tentang penggunaan pijat untuk menurunkan oedema, seperti pada kasus oedema fisiologis pada ibu hamil dapat dilakukan intervensi pijat kaki seperti penelitian yang dilakukan oleh (Çoban \& Şirin, 2010), dimana pijat kaki dapat menurunkan oedema fisiologis pada ibu hamil (Çoban \& Şirin, 2010). Pada kasus oedema kaki akibat limfadema juga dapat dilakukan proses pemijatan seperti penelitian yang dilakukan oleh (Kriederman et al., 2002) tentang efektifitas penggunaan pijat dan atau juga penggunaan penekan (bandage/compression) mampu mengurangi jumlah cairan pada kondisi limfedema (Kriederman et al., 2002).

Pada kasus oedema kaki akibat post-operasi pasien gangguan sistem kardiovaskuler yang dilakukan penelitian oleh Hattan, King, \& Griffiths (2002) dengan melakukan pijat kaki dan imajinasi terbimbing menunjukan bahwa intervensi tersebut dapat menurunkan oedema dan kecemasan pasien postoperasi sistem cardiovaskuler (Hattan et al., 2002). Pada kasus oedema akibat postoperasi juga dapat dilakukan proses pemijatan seperti penelitian yang dilakukan oleh Haren, Backman, \& Wiberg (2000), dimana proses intervensi pijat dapat digunakan untuk menurunkan oedema akibat post-operasi (Haren et al., 2000). 
Proses pemijatan dapat meningkatkan alitan darah sekaligus meningkatkan aliran sirkulasi limfatik pada jaringan tersebut. Proses pemijatan dengan penekanan akan mengenai pembuluh darah, pada pembuluh darah tersebut akan tertekan dan terdorong dengan proses pemijatan, sehingga aliran darah akan menuju ke bagian yang lebih proksimal, demikian juga akan terjadi permeabilitas dinding pembuluh darah (Goats, 1994). Demikian juga pada pembuluh limfe, dengan proses penekanan pada pemijitan tersebut akan merangsang aliran cairan dari bagian interstisial sel akan menuju ke bagian dalam pembuluh limfe yang selanjutnya akan di alirkan ke bagian proskimal pada pembuluh limfe tersebut. Selanjutnya cairan akan dibawa kembali ke sistem vaskuler di muara saluran limfe di atrium dextra jantung. Mekanisme yang terjadi pada pembuluh limfe tersebut yang menjadikan pijat sering disebut sebagai pijat limfatik atau limph drainage (Ekici, Bakar, Akbayrak, \& Yuksel, 2009).

Sama dengan penelitian oleh Goats (1994), hasil studi literatur oleh Weerapong et al. (2005) menunjukan bahwa manfaat pijat sangat banyak salah satu diantaranya adalah meningkatkan kecepatan aliran darah, dimana dengan proses pijat dengan mekanisme penekanan (pressure) akan menekan pembuluh darah di sekitar area pemijatan tersebut sehingga pembuluh darah dapat berdilatasi dan konstriksi sehingga melemaskan otot polos pada pembuluh darah tersebut yang pada akhirnya meningkatkan aliran darah di area tersebut. Proses pemijatan selain berefek pada pembuluh darah juga berefek pada darah, sehingga dengan proses pijat akan mengalirkan darah dari area distal tubuh ke arah proksimal tubuh, sehingga akan berefek juga dalam memperlancar aliran darah (Weerapong et al., 2005).

Dalam penelitian ini, secara statistik dan secara klinis menunjukan ada penurunan dalam lingkar oedema, namun peneliti belum dapat memastikan keefektifan intervensi pijat kaki tersebut, karena pasien menerima terapi medikasi diuretik lasix dan atau furosemide dalam terapi yang diberikannya, bisa dimungkinkan penurunan oedema tersebut akibat efek dari pemberian medikasi tersebut, seperti penelitian Fogari (2005), menunjukan bahwa pasien yang mengalami eodema dapat diberikan terapi diuretik untuk menurunkan oedema tersebut (Fogari, 2005), sehingga peneliti akan merencanakan penelitian lanjutan dengan prosedur pijat kaki tersebut dengan membandingkan dengan adanya kelompok kontrol yang tidak diberikan terapi pijat kaki sekaligus mengontrol penggunaan obat diuretik. 
Banyak hasil literatur menunjukan banyak manfaat penggunaan pijat yang lain diantaranya adalah menurunkan kecemasan, sterss, nyeri, mual, muntah, dapat meningkatkan kenyamanan dan meningkatkan respon fisiologis tubuh (menurunkan tekanan darah sistolik dan diastolik, menurunkan denyut jantung, menurunkan respiratory rate, meningkatkan saturasi oksigen) (Ågren \& Berg, 2006; Li, Wang, Feng, Yang, \& Sun, 2014; Munk, Kruger, \& Zanjani, 2011; Quinn, Chandler, \& Moraska, 2002; Ware, 1903). Hasil penelitian menunjukan terdapat perubahan lingkar oedema pada pasien CHF yang mengalami oedema kaki setelah diberikan intervensi pijat kaki setelah intervensi pemijatan pada hari kedua dan ketiga dengan $p$-value $<0,001$.

\section{KESIMPULAN}

Berdasarkan hasil penelitian dan pembahasan tentang pijat kaki untuk menurunkan oedema kaki pada pasien Congestive Heart Failure (CHF) dapat disimpulkan bahwa pijat kaki efektif untuk menurunkan oedema kaki pada pasien $\mathrm{CHF}$ setelah hari kedua dan hari ketiga dengan $p$-value $<0,001$. Perlu penelitian lanjutan tentang pijat kaki yang menggunakan kelompok kontrol yang tidak diberikan terapi pijat kaki sekaligus mengontrol penggunaan obat diuretik.

\section{ACKNOWLEDGEMENT}

Terimakasih kami sampaikan kepada Direktorat Riset dan Pengabdian Masyarakat, Direktur Jenderal Penguatan Riset dan Pengembangan, Kementerian Riset, Teknologi dan Pendidikan Tinggi, yang telah membiayai proses penelitian ini dalam skema Penelitian Dosen Pemula tahun 2018.

\section{DAFTAR PUSTAKA}

Ågren, A., \& Berg, M. (2006). Tactile massage and severe nausea and vomiting during pregnancy - Women's experiences. Scandinavian Journal of Caring Sciences, 20, 169-176. https://doi.org/10.1111/j.1471-6712.2006.00394.x

AuCoin, A. (2011). Management of a patient with congestive heart failure and acute pulmonary edema - A case study. Canadian Journal of Respiratory Therapy, 47(1), 12-17.

Bayrakci Tunay, V., Akbayrak, T., Bakar, Y., Kayihan, H., \& Ergun, N. (2010). Effects of mechanical massage, manual lymphatic drainage and connective tissue manipulation techniques on fat mass in women with cellulite. Journal of the European Academy of Dermatology and Venereology, 24(2), 138-142. https://doi.org/10.1111/j.14683083.2009.03355.x 
Jurnal IImu Keperawatan Medial Bedah 2 (1), Mei 2019, 1-54

ISSN 2338-2058 (print), ISSN 2621-2986 (online)

Be, S. M., Into, I., \& Hospitals, Q. (2013). Literary review compilation on massage Compiled by AQTN , 2013 INTEGRATED INTO What is the opportunity cost?

Chatterjee, K. (2002). Congestive Heart Failure What Should Be the Initial Therapy and Why? American Journal Cardiovascular Drugs, 2(1), 1-6.

Chen, W.-L., Liu, G.-J., Yeh, S.-H., Chiang, M.-C., Fu, M.-Y., \& Hsieh, Y.-K. (2013). Effect of Back Massage Intervention on Anxiety, Comfort, and Physiologic Responses in Patients with Congestive Heart Failure. The Journal of Alternative and Complementary Medicine, 19(5), 464-470. https://doi.org/10.1089/acm.2011.0873

Cho, S., \& Atwood, J. E. (2002). Peripheral edema. American Journal of Medicine, 113(7), 580586. https://doi.org/10.1016/S0002-9343(02)01322-0

Ciocon, J. O., Galindo-Ciocon, D., \& Galindo, D. J. (1995). Raised leg exercises for leg edema in the elderly. Angiology, 46(1), 19-25. https://doi.org/10.1177/000331979504600103

Çoban, A., \& Şirin, A. (2010). Effect of foot massage to decrease physiological lower leg oedema in late pregnancy: A randomized controlled trial in Turkey. International Journal of Nursing Practice, 16(5), 454-460. https://doi.org/10.1111/j.1440-172X.2010.01869.x

Collier, P., Watson, C. J., Voon, V., Phelan, D., Jan, A., Mak, G., .. Mcdonald, K. M. (2011). Can emerging biomarkers of myocardial remodelling identify asymptomatic hypertensive patients at risk for diastolic dysfunction and diastolic heart failure? European Journal of Heart Failure, 13, 1087-1095. https://doi.org/10.1093/eurjhf/hfr079

Desai, A. S., Lewis, E. F., Li, R., \& Solomon, S. D. (2012). Rationale and design of the Treatment of Preserved Cardiac Function Heart Failure with an Aldosterone Antagonist Trial: A randomized, controlled study of spironolactone in patients with symptomatic heart failure and preserved ejection fraction. American Heart Journal, 162(6), 966-972.e10. https://doi.org/10.1016/j.ahj.2011.09.007

Dinas Kesehatan Republik Indonesia. (2013). Riset Kesehatan Dasar 2013. Riset Kesahatan Dasar, 111-116. https://doi.org/1 Desember 2013

Ekici, G., Bakar, Y., Akbayrak, T., \& Yuksel, I. (2009). Comparison of Manual Lymph Drainage Therapy and Connective Tissue Massage in Women With Fibromyalgia: A Randomized Controlled Trial. Journal of Manipulative and Physiological Therapeutics, 32(2), 127-133. https://doi.org/10.1016/j.jmpt.2008.12.001

Ely, J. W., Osheroff, J. a., Chambliss, M. L., \& Ebell, M. H. (2006). Approach to Leg Edema of Unclear Etiology. The Journal of the American Board of Family Medicine, 19(2), 148-160. https://doi.org/10.3122/jabfm.19.2.148

Fogari, R. (2005). Ankle oedema and sympathetic activation. Drugs, 65 Suppl 2, 21-7. https://doi.org/10.2165/00003495-200565002-00004

Gazillo, L. M., \& Middlemas, D. a. (2001). Therapeutic massage techniques. Aquatic Therapy Today, 6(3), 5-9.

Goats, G. (1994). Massage - the scientific basis of an ancient art: part 2 . Physiological and therapeutic effects. BJSM: Britain Journal Specials Medicine, 2(28), 153-156.

Haren, K., Backman, C., \& Wiberg, M. (2000). EFFECT OF MANUAL LYMPH DRAINAGE AS DESCRIBED BY VODDER ON OEDEMA OF THE HAND AFTER FRACTURE OF THE DISTAL RADIUS : A PROSPECTIVE CLINICAL STUDY. Scandinavian Journal Plastics Reconstruction Hand Surgical, 34, 367-372.

Hattan, J., King, L., \& Griffiths, P. (2002). The impact of foot massage and guided relaxation following cardiac surgery: a randomized controlled trial. Journal of Advanced Nursing, 37(2), 199-207.

Kasron / Pijat kaki efektif menurunkan foo oedema pada penderita ....... Page 24 of $\mathbf{5 4}$ 
Hulme, J., Waterman, H., \& Hillier, V. F. (1999). The effect of foot massage on patients' perception of care following laparoscopic sterilization as day case patients. Journal of Advanced Nursing, 30(2), 460-8. https://doi.org/10.1046/j.1365-2648.1999.01101.x

Kriederman, B., Myloyde, T., Bernas, M., Preciado, S., Lynch, M., Summers, P., ... Mitte, M. (2002). LIMB VOLUME REDUCTION AFTER PHYSICAL TREATMENT BY COMPRESSION AND / OR MASSAGE IN A RODENT MODEL OF PERIPHERAL LYMPHEDEMA. Lymphology, 35, 23-27.

Li, Y., Wang, F., Feng, C., Yang, X., \& Sun, Y. (2014). Massage Therapy for Fibromyalgia: A Systematic Review and Meta-Analysis of Randomized Controlled Trials. PLoS ONE, 9(2), e89304. https://doi.org/10.1371/journal.pone.0089304

Munk, N., Kruger, T., \& Zanjani, F. (2011). Massage Therapy Usage and Reported Health in Older Adults Experiencing Persistent Pain. The Journal of Alternative and Complementary Medicine, 17(7), 609-616. https://doi.org/10.1089/acm.2010.0151

Murberg, T. A., \& Bru, E. (2001). Social relationships and mortality in patients with congestive heart failure. Journal of Psychosomatic Research, 51, 521-527.

Panel, P., Robert, A., Moe, G. W., Co-chair, F., Cheung, A., Costigan, J., ... Leblanc, M. (2011). The 2011 Canadian Cardiovascular Society Heart Failure Management Guidelines Update : Focus on Sleep Apnea, Renal Dysfunction, Mechanical Circulatory Support, and Palliative Care. CJCA, 27(3), 319-338. https://doi.org/10.1016/j.cjca.2011.03.011

Patient, T. (2010). X-Plain Massage Therapy, 1-10.

Quinn, C., Chandler, C., \& Moraska, A. (2002). Massage therapy and frequency of chronic tension headaches. American Journal of Public Health, 92(10), 1657-1661. https://doi.org/10.2105/AJPH.92.10.1657

Ragsdale, B. L. (n.d.). A Massage a Day Could Keep Stress Away.

Rahnavard, Z., Nodeh, Z. H., \& Hatamipour, K. (2014). Congestive heart failure: Predictors of health-related quality of life in Iranian women. Contemporary Nurse, 47(1-2), 159-167.

Remme, W., \& Swedberg, K. (2001). Task Force Report Guidelines for the diagnosis and treatment of chronic heart failure Task Force for the Diagnosis and Treatment of Chronic Heart Failure ,. European Heart Journal, 22, 1527-1560. https://doi.org/10.1053/euhj.2001.2783

Savage, M. P., Krolewski, A. S., Kenien, G. G., Lebeis, M. P., Christlieb, A. R., \& Lewis, S. M. (1998). Acute Myocardial Infartion in Diabetes Mellitus and Significance of Congestive Heart Failure as a Prognostic Factor. The American Journal of Cardiology, 62(October), 665669.

Shimizu, Y. (2009). 妊婦を対象としたフットケアの検討と効果の検証 The effect of foot care for pregnant women. J.Jpn.Acad.Midwif., 23(2), 171-181.

Soran, O. Z., Piña, I. L., Lamas, G. a., Kelsey, S. F., Selzer, F., Pilotte, J., ... Feldman, A. M. (2008). A Randomized Clinical Trial of the Clinical Effects of Enhanced Heart Failure Monitoring Using a Computer-Based Telephonic Monitoring System in Older Minorities and Women. Journal of Cardiac Failure, 14(9), 711-717. https://doi.org/10.1016/j.cardfail.2008.06.448

Trayes, K. P., Studdiford, J. S., Jefferson, T., Tully, A. S., \& Clinic, C. (2013). Edema: Diagnosis and Management.

Ware, M. W. (1903). Massage and the Original Swedish Movements. Annals of Surgery, 37, 639640. https://doi.org/10.1001/jama.1890.02410160034013

Weerapong, P., Hume, P. a., \& Kolt, G. S. (2005). The mechanisms of massage and effects on Kasron / Pijat kaki efektif menurunkan foo oedema pada penderita ....... Page 25 of $\mathbf{5 4}$ 
Jurnal IImu Keperawatan Medial Bedah 2 (1), Mei 2019, 1-54

ISSN 2338-2058 (print), ISSN 2621-2986 (online)

performance, muscle recovery and injury prevention. Sports Medicine, 35(3), 235-256. https://doi.org/10.2165/00007256-200535030-00004

World Health Organization (WHO). (2015). Indonesia: WHO statistical profile. Country Statistics and Global Health Estimates. Retrieved http://who.int/gho/mortality_burden_disease/en/ 